\title{
Development, characterization, and shelf-life of lactose-free artisan ice cream produced with different bases
}

\author{
Desenvolvimento, caracterização e prazo de validade de sorvetes artesanais sem lactose produzido \\ com diferentes bases
}

\section{Desarrollo, caracterización y caducidad de helado artesanales sin lactosa elaborados con diferentes \\ bases}

Received: 02/05/2021 | Reviewed: 02/12/2021 | Accept: 07/10/2021 | Published: 07/20/2021

Ariane Barbosa Alves
ORCID: https://orcid.org/0000-0001-5758-018X
Federal Institute of Education, Science and Technology of Mato Grosso, Brazil
Ealdiney Fernandes dos Santos Junior
ORCID: https://orcid.org/0000-0003-2417-143X
E-mail: waldineyjr@ @mail.com
Wanessa Costa Silva Faria
Federal Institute of Education, Science and Technology of Mato Grosso, Brazil
ORCID: https://orcid.org/0000-0003-1656-5498
E-mail: nessacsf@yahoo.com.br
Edgar Nascimento
Federal Institute of Education, Science and Technology of Mato Grosso, Brazil
Federal Institute of Education, Science and Technology of Mato Grosso, Brazil
E-mail: edgar.nascimento@blv.ifmt.edu.br
Marilu Lanzarin
ORCID: https://orcid.org/0000-0001-9838-4011
E-mail: marilu.lanzarin@ @blv.ifmt.edu.br
Priscila Becker Siqueira
Federal Institute of Education, Science and Technology of
ORCID: https://orcid.org/0000-0001-6282-3991
Federal University of Mato Grosso, Brazil
E-mail: pribecker@gmail.com
Federal Institute of Education, Science and Technology of Mato Grosso, Brazil
E-mail: wander.barros@blv.ifmt.edu.br

\begin{abstract}
This study aims to determine the commercial expiration date of and characterize lactose-free artisanal ice cream with dairy and non-dairy bases. We evaluated four ice cream with different bases at $0,7,14$, and $21 \mathrm{~d}$ of storage. Their centesimal composition was analyzed for proteins, lipids, ashes, carbohydrates, and moisture. The physicochemical properties analyzed included overrun, density, titratable acidity, $\mathrm{pH}$, water activity, and total soluble solids. The $\mathrm{L}^{*}, \mathrm{a}^{*}$, $\mathrm{b}^{*}, \mathrm{C}^{*}$, and $\mathrm{h}^{*}$ parameters were used to evaluate color. Microbiological analyses included Salmonella sp., coagulasepositive Staphylococci, coliforms at $45^{\circ} \mathrm{C}$, and mesophilic and psychrotrophic heterotrophic bacteria. Sensory analysis analyzed the consumer profile and measured their acceptance and intent to purchase the samples, with the zero-lactose milk base obtaining the best nutritional values, the best sensory characteristics, and more than $70 \%$ intent to purchase, indicating that it is the most accepted formulation. All treatments had a shelf life of $21 \mathrm{~d}$ at $-18^{\circ} \mathrm{C}$.
\end{abstract}

Keywords: Innovation; Food product; Shelf life; Vegan food; Ice cream.

\section{Resumo}

Este trabalho tem como objetivo determinar o prazo de validade comercial e caracterizar sorvetes artesanais sem lactose à base de leite e não lácteos. Foram avaliados quatro sorvetes com diferentes bases aos $0,7,14$ e 21 dias de armazenamento. Sua composição centesimal foi analisada para proteínas, lipídios, cinzas, carboidratos e umidade. As propriedades físico-químicas analisadas incluíram superação, densidade, acidez titulável, $\mathrm{pH}$, atividade de água e 
sólidos solúveis totais. Os parâmetros $\mathrm{L} * \mathrm{a} * \mathrm{~b} *, \mathrm{C} * \mathrm{e}$ * foram usados para avaliar a cor. As análises microbiológicas incluíram Salmonella sp., Staphylococci coagulase-positiva, coliformes a $45^{\circ} \mathrm{C}$ e bactérias heterotróficas mesofílicas e psicrotróficas. A análise sensorial analisou o perfil do consumidor e mediu sua aceitação e intenção de compra das amostras, com o leite à base de zero lactose obtendo os melhores valores nutricionais, as melhores características sensoriais e mais de $70 \%$ de intenção de compra, indicando que é o máximo formulação aceita. Todos os tratamentos tiveram uma vida útil de 21 dias a $-18^{\circ} \mathrm{C}$.

Palavras-chave: Inovação; Produto alimentício; Prazo de validade; Alimento vegano; Sorvete.

\section{Resumen}

Este trabajo tiene como objetivo determinar la vida útil comercial y caracterizar el helado artesanal sin lactosa a base de leche y no lácteos. Se evaluaron cuatro helados con diferentes bases a los 0, 7, 14 y 21 días de almacenamiento. Su composición próxima se analizó en busca de proteínas, lípidos, cenizas, carbohidratos y humedad. Las propiedades fisicoquímicas analizadas incluyeron resiliencia, densidad, acidez titulable, $\mathrm{pH}$, actividad del agua y sólidos solubles totales. Se utilizaron los parámetros $\mathrm{L} *, \mathrm{a} *, \mathrm{~b} *, \mathrm{C} *$ yh * para evaluar el color. Los análisis microbiológicos incluyeron Salmonella sp., Estafilococos coagulasa positivos, coliformes a $45^{\circ} \mathrm{C}$ y bacterias heterótrofas mesófilas y psicrotróficas. El análisis sensorial analizó el perfil del consumidor y midió su aceptación e intención de compra de las muestras, obteniendo la leche cero lactosa los mejores valores nutricionales, las mejores características sensoriales y más del $70 \%$ de intención de compra, indicando que es la máxima redacción aceptada. Todos los tratamientos tuvieron una vida útil de 21 días a $-18^{\circ} \mathrm{C}$.

Palabras clave: Inovação; Produto alimentício; Prazo de validade; Comida vegana; Sorvete.

\section{Introduction}

Approximately $65 \%$ to $75 \%$ of the global population is lactose-intolerant (Batista et al., 2018; Marciana et al., 2019). Therefore, there is a demand for lactose-free products. Particularly, 40\% of Brazilians is lactose-intolerant (Branco et al., 2017; Batista et al., 2018). Poor lactose digestion occurs due to decreased activity or absence of $\beta$-galactosidase, better known as lactase (Wooten, 2010). According to Voet (2008), lactose is a disaccharide formed by glucose and galactose that is hydrolyzed by intestinal $\beta$-D-galactosidase or lactase, thus releasing its monosaccharide components into the bloodstream. Galactose is enzymatically converted into glucose, the main metabolic fuel in many tissues. Dairy products or those containing lactose can cause gastrointestinal symptoms, such as diarrhea, vomiting, abdominal colic, and gases, in lactose-intolerant individuals (Suri et al., 2018).

The development of new food products brings numerous advantages, including improved quality and increased variety for consumers and higher profit and decreased production costs for the manufacturers (Abreu, 2012). Ice cream is an excellent source of energy, protein, carbohydrates, and lipids (Almeida et al., 2016).

Soy extract and its derivatives are the main alternatives to cow's milk; however, but its acceptance is limited by its beany flavor caused by the action of lipoxygenase released during the rupture of soybeans. Rice extract, a hypoallergenic product with mild flavor and considerable nutritional value, has also been used. To address dietary calcium deficiency, healthier foods containing calcium as an additive have been developed. In Brazil, kale (Brassica oleracea L. acephala variety) consumption has increased possibly due to its nutritional properties and new gastronomic options (Novo et al., 2010). In addition to being a good source of minerals, phosphorus, vitamins, fiber, calcium, among others (Calheiros; Brazaca, Souza, 2008), kale is easy to grow, harvested all year round, and widely used as a side dish. Yellow passion fruit (Passiflora edulis f. flavicarpa) is a fruit rich in fiber, mineral salts, such as potassium, phosphorus, and magnesium, and bioactive compounds, such as carotenoids and vitamin A (Silva \& Mercadante, 2002; Zeraik et al, 2010). Brazil is its largest producer and exporter globally, and P. edulis f. flavicarpa Deg. is the most cultivated and commercialized variant and used in juice production (Zeraik et al., 2010). Tahiti lime (Citrus latifolia - Tanaka), the fourth fruit most produced in Brazil, after orange, pineapple, and grape, has an annual production of 1,262,353 tons and more than BRL 1 million (IBGE, 2017) and is a very rich source of vitamin C (Viana, 2010). These fruits are new flavor alternatives to incorporate into ice cream as they are a good source of nutrients, especially for lactose-intolerant people. 
Thus, this study aims to develop and characterize different lactose-free artisanal ice cream produced from dairy and non-dairy bases in terms of nutritional, sensory, and physical-chemical characteristics, color, and hygienic-sanitary parameters. We also established their shelf life to meet the demands of the food industry for innovative lactose-free formulations aimed at lactose-intolerant people and those seeking a healthy diet.

\section{Methodology}

\subsection{Materials}

Yellow passion fruit (Passiflora edulis f. flavicarpa Deg.), Tahiti lime (Citrus latifolia - Tanaka), kale (Brassica oleracea L. acephala variety), sucrose (refined sugar/Da Barra ${ }^{\circledR}$ ), glucose powder (Marvi®), stabilizer and emulsifier $\left(\right.$ Emustab $\left.{ }^{\circledR}\right)$, mineral water $\left(\right.$ Lebrinha $\left.{ }^{\circledR}\right)$, rice extract $\left(\right.$ Jasmine $\left.{ }^{\circledR}\right)$, and zero-lactose milk (Piracanjuba $\left.{ }^{\circledR}\right)$ used in the study were obtained from supermarkets in Cuiabá, MT. The rice extract and zero-lactose milk were purchased as ready to consume (UHT Ultra High Temperature), so the ice cream mass did not need to be pasteurized.

\subsection{Experimental design}

The research was conducted with four factors, there were: A: mineral water, B: rice extract, C: zero-lactose milk, and D: 1:1 rice extract:zero-lactose milk mixture, both in same concentration in ice-cream basis. Each basis was developed in three repetitions, which were analyzed in triplicate. They e shelf-life was analyzed under $0,7,14$, and 21 days of storage, unless otherwise indicated. This quantitative study used a completely randomized design (Pereira, et al., 2018).

\subsection{Development of lactose-free ice cream}

All stages of ice cream production until syrup preparation were conducted in the processing laboratory of the Graduate Program in Food Science and Technology of the Federal Institute of Education, Science and Technology of Mato Grosso (IFMT), Cuiabá campus, Bela Vista, MT and was finalized in an ice cream parlor in the city of Cuiabá, MT. The concentration of each ingredient was determined according to the results of the preliminary tests. The formulations used are listed in Table 1.

Table 1. Formulation of different non-lactose ice cream bases.

\begin{tabular}{lcccc}
\hline Ingredient & A & B & C & D \\
\cline { 2 - 5 } Kale & 160 & 160 & 160 & 160 \\
Sour passion fruit & 100 & 100 & 100 & 100 \\
Tahiti lime & 50 & 50 & 50 & 50 \\
Glucose powder & 95 & 95 & 95 & 95 \\
Sucrose & 90 & 90 & 90 & 90 \\
Stabilizer & 2 & 2 & 2 & 2 \\
Emulsifier & 1 & 1 & 1 & 1 \\
Mineral water & 502 & - & - & - \\
Rice extract & - & 502 & - & 251 \\
Zero-lactose milk & - & - & 502 & 251 \\
Total & 1000 & 1000 & 1000 & 1000 \\
\hline
\end{tabular}

A: mineral water base; B: rice extract base; C: zero-lactose milk base; D: mixed base. Source: Authors (2021). 
Initially, the ingredients were selected at the place of purchase. Fruits and vegetables with undesirable defects, such as lesions, cracks, and insects, were avoided, as well as possibly outdated raw materials. The products were washed in running water and sanitized in $2.5 \%$ (v/v) sodium hypochlorite solution for $10 \mathrm{~min}$. Sour passion fruit, Tahiti lime, and kale were manually cut; passion fruit was pulped; lime juice was collected using a fruit squeezer (Mondial Turbo Citrus, E-01, Brazil). The ingredients were stored under refrigeration in hermetically sealed containers until further analysis, five min after weighing.

All raw materials were weighed using a semi-analytical scale (Balmak, ELC-15BS, Brazil), and the appropriate quantities required for each formulation was prepared and mixed in a low rotation industrial blender $(800 \mathrm{~W})$ for $20 \mathrm{~s}$ (Colombo, Br 8L Inox, Itajobi, SP, Brazil). Each ice cream base was defined in this step, with zero-lactose milk, rice extract, mineral water, or zero-lactose milk and rice extract being $(1: 1 \mathrm{~m} / \mathrm{m})$ being added according to the formulation. The liquid obtained in this step was called syrup.

Then, each base was placed in a discontinuous horizontal ice cream maker (Techno Frisher, PHD 100, São Carlo- SP, Brazil) for $40 \mathrm{~min}$. At this stage, the syrup was homogenized, incorporated with air, and frozen simultaneously, transforming it into a consistent and soft mass. Finally, the ice cream obtained was weighed, packed in $350 \mathrm{ml}$ transparent containers, and stored in a vertical frseezer (Brastemp Frost Free Flex BVR28HR Inox - 228 L, São Paulo- SP, Brazil) at $-18{ }^{\circ} \mathrm{C}$ for subsequent analyses.

\subsection{Analyses}

\subsubsection{Centesimal analysis}

Centesimal composition was analyzed according to the IAL guidelines (2008). Moisture content was evaluated using the gravimetric method in an air circulation oven (SPLabor; Model: SP-100/100) (012/IV); ashes, residue incineration method, muffle furnace (Zezimaq; Model: 2000-F) at $550{ }^{\circ} \mathrm{C}(018 / \mathrm{IV})$; proteins, Kjeldahl method (36/IV) using a conversion factor of 6.25; and lipids, Rose-Gottlieb method (412/IV). Carbohydrates were estimated based on the difference between values found in the other analyses.

\subsubsection{Overrun test}

We measured the amount of air incorporated into the ice cream mass using the overrun test. The ratio between the air volume and liquid volume was calculated and expressed in percentage (Clarke, 2004). Equation 1 below was used to compute for the overrun according to Goff and Hartel (2004):

$$
\% \text { overrun }=\frac{\text { mixture }- \text { ice } \text { creamM }}{\text { ice } \text { cream } M} \times 100 \text { (Eq.1) }
$$

where mixture $_{\mathrm{M}}=$ mass before production (syrup); and ice $\mathrm{cream}_{\mathrm{M}}=$ mass after production and air incorporation (ice cream).

\subsubsection{Physicochemical analysis}

Characterization of the ice cream samples was assessed after $0,7,14$, and $21 \mathrm{~d}$ of storage. $\mathrm{pH}$ analysis was conducted using direct potentiometry with a digital benchtop pH meter (Hanna Instruments, HI 2221, Tamboré Barueri, SP, Brazil), after calibration with buffer solutions 4 and 7 according to method No. 981.12 of the Association of Official Analytical Chemists (AOAC, 2012). Titratable acidity (TA) was determined based on the neutralization titration of $0.1 \mathrm{~N} \mathrm{NaOH}$, and a color change of light green to pink was the endpoint. Results are expressed in mass of organic acid/mass of ice cream. Density was measured using the Gay-Lussac pycnometer without a 100-mL thermomete and expressed in $\mathrm{g} / \mathrm{L}$; water activity (wA) was measured using a digital water activity analyzer (Aqualab series 4TE, São José dos Campos, São Paulo, Brazil) by dew point using the sample 
temperature as an internal control using the AOAC method 978.18 and ASTM method D6836 02 (2008) and expressed in \% wA; total soluble solids (TSS) was measured directly according to the AOAC (2012) method 20932.12 and using a portable digital refractometer and benchtop scale 0-95\% Brix (Instrutherm mod. RTD-95, São Paulo, Brazil) and expressed in ${ }^{\circ}$ Brix.

\subsubsection{Color evaluation}

Color was evaluated using the CIELAB system $\left(L^{*} a^{*} b^{*}\right)$, wherein $L^{*}$ (luminosity) indicates the degree of color brightness (i.e., light or dark), and $\mathrm{a}^{*}$ and $\mathrm{b} *$ shades conducted on a portable spectrophotometer (Konica Minolta, Model CM$700 \mathrm{~d}$, Japan). The samples were analyzed after $0,7,14$, and $21 \mathrm{~d}$ of storage. Color intensity in the plane $\left(\mathrm{a}^{*}, \mathrm{~b}^{*}\right)$ was analyzed based on saturation (strong or weak) via the chroma result $\left(\mathrm{C}^{*}\right)$, and the hue color shade $\left(\mathrm{h}^{*}\right)$ was analyzed based on the angle. Equation 2 was used to calculate the saturation index $\left(\mathrm{C}^{*}\right)$, and equation 3 was used to calculated the hue angle (h*) (Ramos \& Gomide, 2007).

$$
C *=\sqrt{(a *)^{2}+(b *)^{2}}
$$

$$
h *=\arctan (b * / a *)(2)
$$

wherein $\mathrm{C}^{*}$ represents saturation (chroma); $\mathrm{a}^{*}$ represents the green $(-)$ or red tone $(+) ; \mathrm{b}^{*}$ represents the blue $(-)$ or yellow tone (+); and $\mathrm{h} *$ represents the tonal angle (hue)

\subsubsection{Microbiological analysis}

Microbiological analysis was performed at the Food Microbiology Laboratory of the Federal Institute of Education, Science and Technology of Mato Grosso (IFMT), Cuiabá campus, Bela Vista, Cuiabá, MT.

According to the RDC guideline No. 12 revised as of January 2, 2001 (Brazil, 2001), for ice cream to be considered fit for consumption, samples must be analyzed for hygiene and sanitary quality. Thus, ice cream produced using dairy bases require Salmonella sp. analyses according to the ISO 6579 method, coliform quantification at $45^{\circ} \mathrm{C}$ according to APHA Placement Method: 2015 and AHPA/AWWA/WEF 9221:2012, and the quantification of coagulase-positive Staphylococci according to the ISO 6888-1:1999/Amd 1:2003 Plate Method (Silva et al., 2017). Salmonella sp. and coliform quantification at $45{ }^{\circ} \mathrm{C}$ were performed for non-dairy bases.

Ice cream bases were analyzed to quantify the heterotrophic aerobic mesophilic bacteria according to the APHA Plate Method 08:2015 and the psychotrophic aerobic mesophilic bacteria according to the APHA Plate Method 13.61:2015 (Silva et al., 2017).

\subsubsection{Sensory analysis}

Sensory analysis was performed at the Laboratory of Sensory Analysis of the School of Food Engineering of IFMT, Cuiabá campus, Bela Vista, Cuiabá. The study protocol for sensory analysis was approved by the Ethics Committee of the Federal Institute of Education, Science and Technology of Mato Grosso (CAAE opinion number 87608718.6.0000.8055), and informed consent was obtained from all participants.

Ice cream samples that were stored at 7 and $21 \mathrm{~d}$ were included in the sensory analysis to verify sample acceptance and determine whether the consumers observed organoleptic differences due to shelf life. The ice cream samples were tasted by 100 habitual ice-cream consumers aged between 18-50 years for each storage time.

To obtain initial information on hygienic and sanitary quality, which are recommended by the human research ethics committee and must be obtained before the beginning of sensory analysis studies, sample tasting was only started after storage 
for $7 \mathrm{~d}$ as microbiological analysis was first conducted. However, to ensure that the four formulations were fit for consumption, all analyses required by the RDC 12/2001 for dairy and non-dairy bases were performed.

The sensory tests were performed using an evaluation sheet to analyse the consumer profile, acceptance, and purchasing attitude according to the method by Stone et al. (1974). Consumer profile included sex, age, and frequency of ice cream/gelato consumption; product acceptance was measured using an unstructured hedonic scale of $9 \mathrm{~cm}$, where extreme sides were noted from "extremely disliked" and "extremely liked," for color, flavor, texture, and general impression; intention to buy was measured in a 5-point structured hedonic scale with the following terms: "would certainly buy," "would probably buy," "would maybe buy/not buy," "would probably not buy," and "would certainly not buy."

Samples (30 g each) were served at $-18{ }^{\circ} \mathrm{C}$ in disposable plastic cups with three-digit random numbers in individual booths. Mineral water was freely available to the participants, so they could cleanse their palate between tasting.

\subsection{Statistical analysis}

Sensory analysis used the means of the characteristics for the correlation matrix, and analysis of main components was performed. Eigenvalues and autovectors were found for the grouping of sample variables. The results obtained in the sample acceptance test were subjected to the Kolmogorov-Smirnov normality test, and the means were compared using $t$-test.

For the physical-chemical analysis and color evaluation, data were subjected to the Kolmogorov-Smirnov normality test. For centesimal and microbiological analysis, the results were subjected to the Shapiro-Wilk normality test. For centesimal analysis, physical-chemical analysis and color parameters, the non-normal variables were subjected to the Kruskal-Wallis test, and the means were compared using the Wilcoxon test; normal variables underwent analysis of variance (ANOVA-DIC), and the differentiation of the means was analyzed using Tukey test. The results obtained from the plate count of the mesophilic microorganisms were transformed into a log plot in the base ten and subjected to ANOVA- DIC, and the differentiation of the means was analyzed using Tukey test.

Statistical analysis was performed using the R i386 software v3.6.1 (RC Team, 2019) at 5\% significance level with the ExpDes.pt, agricolae, RcmdrMisc, nortest, plyr, FactoMiner, fatoextra, and corrplot packages.

\section{Results and Discussion}

\subsection{Centesimal analysis}

Table 2 presents the centesimal composition of all ice cream bases.

Table 2. Centesimal composition of different lactose-free ice cream bases.

\begin{tabular}{ccccccc}
\hline Formulation & $\begin{array}{c}\text { Moisture } \\
(\boldsymbol{\%})\end{array}$ & $\begin{array}{c}\text { Protein } \\
(\boldsymbol{\%})\end{array}$ & $\begin{array}{c}\text { Lipid } \\
(\boldsymbol{\%})\end{array}$ & $\begin{array}{c}\text { Ashes } \\
(\boldsymbol{\%})\end{array}$ & $\begin{array}{c}\text { Carbohydrate } \\
(\boldsymbol{\%})\end{array}$ & $\begin{array}{c}\text { Overrun } \\
\text { Test }(\boldsymbol{\%})\end{array}$ \\
\hline $\mathbf{A}$ & $76.78 \pm 1.20 \mathrm{a}$ & $0.31 \pm 0.00 \mathrm{c}$ & $0.88 \pm 0.08 \mathrm{~b}$ & $0.31 \pm 0.01 \mathrm{c}$ & $21.69 \pm 1.10 \mathrm{~b}$ & $5.68 \pm 4.09$ \\
$\mathbf{B}$ & $70.38 \pm 1.51 \mathrm{~b}$ & $0.32 \pm 0.02 \mathrm{c}$ & $1.37 \pm 0.27 \mathrm{a}$ & $0.35 \pm 0.07 \mathrm{c}$ & $27.56 \pm 1.85 \mathrm{a}$ & $6.76 \pm 0.78$ \\
$\mathbf{C}$ & $69.97 \pm 0.23 \mathrm{~b}$ & $2.81 \pm 0.17 \mathrm{a}$ & $1.90 \pm 0.80 \mathrm{a}$ & $0.75 \pm 0.09 \mathrm{a}$ & $24.55 \pm 0.84 \mathrm{ab}$ & $6.11 \pm 2.33$ \\
$\mathbf{D}$ & $71.15 \pm 0.68 \mathrm{ab}$ & $1.15 \pm 0.07 \mathrm{~b}$ & $1.25 \pm 0.08 \mathrm{a}$ & $0.54 \pm 0.05 \mathrm{~b}$ & $25.88 \pm 0.60 \mathrm{a}$ & $5.50 \pm 5.02$ \\
\hline
\end{tabular}

Means with similar letters in the same column do not differ significantly (5\% significance level by Tukey's test); means with similar letters in the same column for moisture, protein, and lipids do not differ significantly (5\% significance level by Wilcoxon's test). Variables without letters are statistically equal. ${ }^{\dagger} \mathrm{A}$ : mineral water base; B: rice extract base; C: zerolactose milk base; D: mixed base. Source: Authors (2021). 
Moisture refers to the total amount of water contained in food (Ribeiro et al., 2018). Treatment A (76.78\%) and D (71.15\%) had the highest moisture content among all formulations; however, B (70.38\%), C (69.97\%), and D did not differ significantly $(p>0.05)$ in terms of moisture content. Carlos et al. (2019) have reported moisture values ranging from 71.54$76.00 \%$ in fruit ice cream. Here, the base directly interfered with the moisture content as treatment A has mineral water, and D has water derived from milk and rice extract, thus increasing the moisture content in the mixed base product.

Milk-based ice cream is rich in mineral salts such as calcium, potassium, phosphorus, and magnesium, among other nutrients such as protein, which is mostly casein (TACO, 2011), which is possible only due to the presence of these components in the ingredients. Treatment $\mathrm{C}$ had the highest amounts of protein $(2.81 \%)$ and ash $(0.75 \%)$ among all four treatments; A $(0.31 \%)$ and B $(0.32 \%)$ had no significant difference $(p>0.05)$ in terms of protein and ash contents (A, $0.31 \%$; B, $0.35 \%)$. However, D had the second highest percentage of proteins (1.15\%) and ashes (0.54\%), which can be attributed to its base. Silva et al. (2015) have analyzed mixed rice extract, passion fruit, and papaya drinks and have reported protein levels ranging from $0.45-0.48 \%$ and ash levels of 1.16-1.55\%. Therefore, the protein content in treatment $\mathrm{D}$ is derived from its bases, i.e., zero-lactose milk and rice extract, whereas the ash content is derived from mineral salts in all the ingredients used in the base, especially kale, lime, and passion fruit.

Carbohydrates and lipids provide energy to the human body, and daily glucose intake is essential to maintain brain functioning. Carbohydrates provide $\sim 4 \mathrm{kcal} / \mathrm{g}$ to the body, and lipids, $9 \mathrm{kcal} / \mathrm{g}$ (Brazil, 2003). These macronutrients are present in bread, desserts, cereals, fruit, vegetables, legumes, among others. All formulations had no significant difference in carbohydrate content (A: 21.69\%; B: 27.56\%; C: 24.55\%; D: 25.88\%; $p>0.05$ ). However, treatment C presented no significant difference $(p>0.05)$ compared to treatment A.

Regarding lipid content, treatment A have the lowest lipid content $(0.88 \%)$ because water does not contain carbohydrate and lipids; there were no significant differences among treatments B (1.37\%), C (1.90\%), and D $(1.25 \%)(p<0.05)$. Carlos et al. (2019) have reported carbohydrate levels ranging from $19.77-21.16 \mathrm{~g} / 100 \mathrm{~g}$ and lipid levels ranging from $0.42-4.29 \mathrm{~g} / 100 \mathrm{~g}$ in fruit ice cream, which are higher and lowers than our results, respectively. Thus, the carbohydrates in our developed ice cream were derived from the sucrose, glucose, and carbohydrates present in other ingredients.

Lipids increase overrun (Fellows, 2018) and milk protein in dairy products as casein stabilizes air bubbles and fat globules in ice cream. This micelle envelopes fat globules, thus stabilizing them and forming an emulsion (Pinhão, 2012). However, the results of the overrun test showed that all samples had no significant difference in terms of air incorporation $(p>$ 0.05). We attribute this to the use of the same equipment during production and the low amount of lipids in the formulation, which directly influenced the accumulation of air in the mass, since it used an ice cream producer with was no air entry, being closed at the ends.

\subsection{Physicochemical analysis}

Table 3 summarizes the physicochemical properties of the different zero-lactose ice cream bases, whereas Table 4 lists the changes in physicochemical properties during storage time. 
Table 3. Physicochemical properties of the different zero-lactose ice cream bases.

\begin{tabular}{cccccc}
\hline Formulation & $\mathbf{p H}$ & $\begin{array}{c}\text { TA } \\
(\mathbf{g} / \mathbf{g})\end{array}$ & $\begin{array}{c}\text { Density } \\
(\mathbf{g} / \mathbf{L})\end{array}$ & $\begin{array}{c}\text { TSS } \\
\left({ }^{\circ} \mathbf{B r i x}\right)\end{array}$ & $\begin{array}{c}\text { wA } \\
(\boldsymbol{\%})\end{array}$ \\
\hline $\mathbf{A}$ & $3.51 \pm 0.10 \mathrm{c}$ & $0.73 \pm 0.10 \mathrm{~b}$ & $1096.51 \pm 7.75 \mathrm{c}$ & $25.22 \pm 4.29 \mathrm{~b}$ & $0.97 \pm 0.00 \mathrm{a}$ \\
$\mathbf{B}$ & $3.58 \pm 0.11 \mathrm{c}$ & $0.76 \pm 0.04 \mathrm{~b}$ & $1122.85 \pm 7.43 \mathrm{a}$ & $28.38 \pm 3.44 \mathrm{a}$ & $0.96 \pm 0.01 \mathrm{~b}$ \\
$\mathbf{C}$ & $4.28 \pm 0.09 \mathrm{a}$ & $0.82 \pm 0.04 \mathrm{a}$ & $1118.46 \pm 4.58 \mathrm{~b}$ & $28.70 \pm 1.56 \mathrm{a}$ & $0.96 \pm 0.01 \mathrm{~b}$ \\
$\mathbf{D}$ & $3.91 \pm 0.08 \mathrm{~b}$ & $0.82 \pm 0.03 \mathrm{a}$ & $1123.82 \pm 1.48 \mathrm{a}$ & $28.84 \pm 1.58 \mathrm{ab}$ & $0.96 \pm 0.01 \mathrm{~b}$ \\
\hline
\end{tabular}

Means with similar letters in the same column do not differ significantly ( $5 \%$ significance level by Wilcoxon test). pH: hydrogen potential; TA: titratable acidity; TSS: total soluble solids; wA: water activity; g/g: gram of organic acid/gram of sample. $\dagger$ A: mineral water base; B: rice extract base; C: zero-lactose milk base; D: mixed base. Source: Authors (2021).

Table 4. Changes in the physicochemical properties of the different zero-lactose ice cream bases after storage.

\begin{tabular}{cccccc}
\hline $\begin{array}{c}\text { Storage period } \\
\text { (days) }\end{array}$ & pH & $\begin{array}{c}\text { TA } \\
(\mathbf{g} / \mathbf{g})\end{array}$ & $\begin{array}{c}\text { Density } \\
(\mathbf{g} / \mathbf{L})\end{array}$ & $\begin{array}{c}\text { TSS } \\
\left({ }^{\circ} \mathbf{B r i x}\right)\end{array}$ & $\begin{array}{c}\text { wA } \\
(\%)\end{array}$ \\
\hline T0 & $3.71 \pm 0.36 \mathrm{~b}$ & $0.75 \pm 0.08 \mathrm{~b}$ & $1115.44 \pm 15.44 \mathrm{a}$ & $27.57 \pm 3.34 \mathrm{a}$ & $0.95 \pm 0.01 \mathrm{~b}$ \\
T1 & $3.82 \pm 0.35 \mathrm{ab}$ & $0.82 \pm 0.05 \mathrm{a}$ & $1114.34 \pm 13.69 \mathrm{a}$ & $28.86 \pm 2.78 \mathrm{a}$ & $0.96 \pm 0.01 \mathrm{a}$ \\
T2 & $3.81 \pm 0.27 \mathrm{ab}$ & $0.80 \pm 0.03 \mathrm{ab}$ & $1115.75 \pm 9.39 \mathrm{a}$ & $27.27 \pm 3.68 \mathrm{a}$ & $0.97 \pm 0.00 \mathrm{a}$ \\
T3 & $3.94 \pm 0.28 \mathrm{a}$ & $0.76 \pm 0.07 \mathrm{~b}$ & $1116.11 \pm 12.62 \mathrm{a}$ & $27.43 \pm 3.27 \mathrm{a}$ & $0.97 \pm 0.00 \mathrm{a}$ \\
\hline
\end{tabular}

Means with similar letters in the same column for wA do not differ significantly (5\% significance level by Tukey's test); means with similar letters in the same column for $\mathrm{pH}$, TA, density, and TSS do not differ significantly (5\% significance level by Wilcoxon's test). $\mathrm{pH}$ : hydrogen potential; TA: titratable acidity; TSS: total soluble solids; wA: water activity; g/g: gram of organic acid/gram of sample. Source: Authors (2021).

The $\mathrm{pH}$ is an importante indicator in product conservation. The $\mathrm{pH}$ values closer to the neutral (7) have greater likelihood of spoilage due to microbial growth (Ribeiro et al., 2018). In table 4, treatments a (3.51) and b (3.58) have the lowest pH with no significant difference; however, the $\mathrm{pH}$ values of $\mathrm{c}(4.28)$ and $\mathrm{d}$ (3.91) were significantly different. treatment $\mathrm{c}$ has the highest pH value among all zero-lactose milk-based ice cream, while fresh milk has a mean pH of 6.7 (brito et al., 2019). Therefore, treatment $\mathrm{c}$ differs significantly from $\mathrm{d}, \mathrm{a}$, and $\mathrm{b}$.

Ice cream $\mathrm{pH}$ and acidity directly influence flavor. fruit ice creams generally have different $\mathrm{pH}$ and acidity than traditional ice cream flavors, such as chocolate and cream (Correia et al., 2008; Almeida et al., 2016). Despite this, the pH values of all formulations did not significantly differ until day 14 ; however, at day 21 , the highest $\mathrm{pH}$ value relative to no storage period was observed $(p>0.05)$.

Acidity represents the concentration of organic acids in the food (Ribeiro et al., 2018). Treatments c $(0.82 \mathrm{~g} / \mathrm{g})$ and $\mathrm{d}$ $(0.82 \mathrm{~g} / \mathrm{g})$ had the highest acidity values, and they have no significant difference. this acidity level is equivalent to $82 \mathrm{~g}$ of citric $\mathrm{acid} / 100 \mathrm{~g}$ of sample, which was much higher than that reported by coelho et al. (2019), i.e., $0.42 \mathrm{~g}$ of citric acid/100 $\mathrm{g}$ in milkbased ice cream with pomegranate pulp. on the other hand, treatments a $(0.73 \mathrm{~g} / \mathrm{g})$ and b $(0.76 \mathrm{~g} / \mathrm{g})$ had lower acidity levels. we attribute this to the milk content of $\mathrm{c}$ and $\mathrm{d}$, and milk contains lactic acid, whereas a (water) and b (rice extract) have low acidity as they did not contain milk. notably, all treatments contained vitamin $\mathrm{c}$ in their base derived from citrus fruits, which further increased their acidity levels. At 7 and $14 \mathrm{~d}$ of storage, the acidity of the sample ice cream increased, but there was no significance in acidity between 0 storage time and 14 and $21 \mathrm{~d}$ of storage.

Density indicates much air was incorporated into the ice cream mass during mixing (Cadena, 2008). We found that treatments b (1122.85 g/l) and d (1123.82 g/l) had the highest density among all formulations (c: $1118.46 \mathrm{~g} / \mathrm{l}$; a: $1096.51 \mathrm{~g} / \mathrm{l})$. 
The rice extract we used contained sunflower oil, which has $0.9 \mathrm{~g} / 200 \mathrm{ml}$ polyunsaturated fats. because lipids are essential for better overrun, this resulted in greater incorporation of air. on the other hand, the mean density values did not significantly differ upon storage $\left(p>0.05\right.$, table 5). Notably, all treatments were within the minimum apparent density required by the $\mathrm{rdc}^{\circ}$ 266/2005 (Brazil, 2005) for ice cream, which is $475 \mathrm{~g} / \mathrm{l}$.

Approximately 85\% of TSS corresponds to sugars (Perfeito, Corrêa; Peixoto, 2017). As shown in Table 4, treatments B (28.38 ${ }^{\circ}$ Brix $), C$ (28.70 ${ }^{\circ}$ Brix $)$, and D (28.84 ${ }^{\circ}$ Brix) have the highest amount of sugars, and no statistical difference was determined among them; however, they are significantly different from $\mathrm{A}\left(25.22^{\circ} \mathrm{Brix}\right)$. On the other hand, the mean Brix values did not significantly change during storage (Table 5). Marroquim et al. (2019) have reported a TSS level between $2.00^{\circ}$ and $4.10^{\circ}$ Brix in fruit-pulp beverages and between 1.85 and $5.50^{\circ}$ Brix in fresh-fruit beverages, indicating that fresh fruits contain

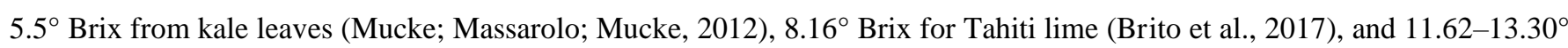
Brix for yellow passion fruit (Botelho et al., 2019). Associated with the added sugars to all ice cream bases, increased the ${ }^{\circ}$ Brix value found in this study.

From Table 4, treatments B $(0.96 \%), \mathrm{C}(0.96 \%)$, and D $(0.96 \%)$ had low levels of free water without significant difference; however, their free water levels significantly differ compared with A $(0.97 \%)$, which has the highest wA value due to its mineral water base. On the other hand, the mean wA values did not significantly change during storage for $7 \mathrm{~d}$ (Table 5). However, the amount of free water without storage was the lowest, which might be because the samples have yet to reach $-18^{\circ}$ C.

\subsection{Color evaluation}

Table 5 summarizes color parameters obtained, whereas Table 6 lists the change in color parameters during storage in the four zero-lactose ice cream samples.

Table 5. Color parameters of the different zero-lactose ice cream bases.

\begin{tabular}{cccccc}
\hline Treatment & $\mathbf{L}^{*}$ & $\mathbf{a}^{*}$ & $\mathbf{b}^{*}$ & $\mathbf{C}^{*}$ & $\mathbf{h}^{*}$ \\
\hline $\mathbf{A}$ & $32.56 \mathrm{c}$ & $6.66 \mathrm{~b}$ & $7.78 \mathrm{c}$ & $81.85 \mathrm{~b}$ & $134.29 \mathrm{~b}$ \\
$\mathbf{B}$ & $39.78 \mathrm{bc}$ & $7.45 \mathrm{a}$ & $13.12 \mathrm{~b}$ & $202.04 \mathrm{~b}$ & $1.27 \mathrm{c}$ \\
$\mathbf{C}$ & $62.08 \mathrm{a}$ & $2.18 \mathrm{~d}$ & $21.43 \mathrm{a}$ & $479.07 \mathrm{a}$ & $178.65 \mathrm{a}$ \\
$\mathbf{D}$ & $44.05 \mathrm{~b}$ & $3.13 \mathrm{c}$ & $19.13 \mathrm{a}$ & $392.70 \mathrm{a}$ & $178.63 \mathrm{a}$ \\
\hline
\end{tabular}

Means with similar letters in the same column for $\mathrm{L}^{*}, \mathrm{~b}^{*}$, and $\mathrm{C}^{*}$ do not differ significantly $(5 \%$ significance level by Tukey's test); means with similar letters in the same column for $\mathrm{a}^{*}$ and $\mathrm{h}^{*}$ do not differ significantly (5\% significance level by Wilcoxon's test). A* values were transformed and added by 7 because negative data were not allowed in the statistical software; however, this did not change the data distribution. $L^{*}$ : luminosity; $a^{*}(a+$ red/a- green); b* $(b+$ yellow/b- blue); $\mathrm{C}^{*}$ : saturation; $\mathrm{h}^{*}$ : hue. A: mineral water base; B: rice extract base; C: zero-lactose milk base; D: mixed base. Source: Authors (2021). 
Table 6. Changes in color paraments during ice cream storage.

\begin{tabular}{cccccc}
\hline $\begin{array}{c}\text { Time } \\
\text { (days) }\end{array}$ & L* & $\mathbf{a}^{*}$ & $\mathbf{b}^{*}$ & $\mathbf{C}^{*}$ & $\mathbf{h}^{*}$ \\
\hline T0 & $51.63 \mathrm{a}$ & $5.15 \mathrm{a}$ & $10.98 \mathrm{c}$ & $151.07 \mathrm{c}$ & $134.10 \mathrm{a}$ \\
T1 & $46.74 \mathrm{ab}$ & $4.85 \mathrm{a}$ & $13.01 \mathrm{bc}$ & $232.14 \mathrm{bc}$ & $134.33 \mathrm{a}$ \\
T2 & $38.03 \mathrm{~b}$ & $4.59 \mathrm{a}$ & $16.33 \mathrm{ab}$ & $300.02 \mathrm{ab}$ & $134.33 \mathrm{a}$ \\
T3 & $42.06 \mathrm{ab}$ & $4.84 \mathrm{a}$ & $21.14 \mathrm{a}$ & $472.43 \mathrm{a}$ & $90.08 \mathrm{a}$ \\
\hline
\end{tabular}

Means with similar letters in the same column do not differ significantly ( $5 \%$ significance level by Wilcoxon's test). $L^{*}$ : luminosity; $a^{*}(a+r e d / a-$ green $) ; b^{*}\left(b+\right.$ yellow/b- blue); $C^{*}$ : saturation; $h^{*}$ : hue. Source: Authors (2021).

After preparation, the samples had different colors: the water base ice cream was dark green; rice extract was greenishyellow; zero-lactose base was bright green, and the mixed rice extract and zero-lactose milk base (1:1 m/m) was opaque green.

Hue $\left(h^{*}\right)$ values of treatments $C(178.65)$ and D $(178,63)$ had no different difference, but were significantly different from those of A (134.29) and B (1.27), which were statistically different. Upon storage, the $\mathrm{h}^{*}$ values of all treatments remained in the range of 100 and 200 (Ramos \& Gomide, 2007), indicating no change in green hue over time.

Different frozen fruit pulps have variations in $\mathrm{L}^{*}, \mathrm{a}^{*}$, and $\mathrm{b}^{*}$, which may be due to the time of harvest, climate, and the maturation index of raw materials, thus resulting in different fruit pigmentations (Santos; Coelho; Carreiro, 2008; Neves \& Lima, 2009; Pereira et al., 2009). The a* values were transformed and added by seven because negative data were not accepted by the statistical software; however, this did not change the data distribution. Table 5 shows that treatment B (7.45) had the highest shade of green $\left(\mathrm{a}^{*}\right)$, indicating greater chlorophyll content (green color) due to its kale content among all formulations (A: 6.66; C: 2.18; D: 3.13), which had significant differences. However, upon storage for up to $21 \mathrm{~d}$, there was no significant change in a* values.

Aragão et al. (2018) have obtained b* values ranging from 44.0 to 51.2 in ice cream with passion fruit pulp, which are higher than our results. Thus, the kale and chlorophyll (green) we used influenced the yellow hue of passion fruit in the final product; thus, yellow color was stronger in treatments C (21.43) and D (19.13), which contained milk in their composition, a white ingredient (Fellows, 2018), showing no statistical difference ( $\mathrm{p}>0.05)$. The water-based treatment A (7.78), an odorless and colorless liquid (Fellows, 2018), and the rice extract-based treatment B (13.12) had a brownish hue owing to the presence of whole grain rice, thus resulting in a lower intensity of yellow hue $\left(b^{*}\right)$ as shown in Table 6. However, according to Table 7, in all treatments, the yellow shade $\left(b^{*}\right)$ value was the highest after 14 and $21 \mathrm{~d}$ of storage with no statistical difference, suggesting the decrease in yellow color and increased in green color over time.

From Table 5, the luminosity $\left(\mathrm{L}^{*}\right)$ value was significantly $(p<0.05)$ the highest in treatment $\mathrm{C}(62.08)$, with a bright green color, making the product the lightest among other treatments (D: 44.95; B: 39.78; and A: 32.56). However, treatments D and B were statistically equal. $\mathrm{L}^{*}$ of the samples did not significantly change during storage as shown in Table 7 , indicating that the treatments remained clear over time.

Finally, in terms of saturation $\left({ }^{*} \mathrm{C}\right)$, treatments $\mathrm{C}(479.07)$ and $\mathrm{D}$ (392.70) were the highest, showing statistical difference with A (81.85) and B (202.04), which had no statistical difference. On the other hand, C* did not significantly change during storage (Table 6), and the highest $* \mathrm{C}$ value was at $21 \mathrm{~d}$.

Vegetable color can be attributed to the presence of carotenoids, anthocyanins, and chlorophyll, and in fruits, color is due to phenolic pigments such as flavanols (Castro et al., 2015). The fruits and vegetables we used are rich in carotenoids (orange/yellow), flavonoids (red/yellow or orange), and chlorophyll (green), which explains the final greenish/yellowish shade of the ice cream samples with higher concentration of kale. 
The variation in color during storage may be associated to peroxidase and polyphenol oxidase, which upon contact with oxygen produce a brownish color in fruits, vegetables, and processed foods. This process is accompanied by the oxidation of vitamin C (Valderrama; Fabiane; Clemente, 2001; Laurenti \& Clemente, 2005). Adabo et al. (2018) have investigated the activity of peroxidase and polyphenol oxidase during storage of fruits subjected to a post-harvest physical process. Another factor is the degree of ripeness of fruits and vegetables. Our results indicate that the vegetable ingredients we used were be at different stages of ripeness. The physical process used for the preparation of the fruits and vegetables may have also led to a color change that affected the shelf life of the products, although they were immediately frozen at $-18^{\circ} \mathrm{C}$.

\subsection{Microbiological analysis}

Table 7 summarizes our microbiological analysis results. None of the treatments contained pathogenic microorganisms, such as Salmonella sp. and the coagulase-positive Staphylococci, and all formulations were suitable for consumption. Only treatment $\mathrm{C}$ presented coliforms at $45^{\circ} \mathrm{C}$; however, its quantity was within the tolerated limit of $5 \times 10 \mathrm{UFC} / \mathrm{g}$ as recommended in the current legislation (Brazil, 2001). Microorganisms, such as coliforms, coagulase-positive Staphylococci, and Salmonella sp., are indicators of hygienic and sanitary conditions. Our results indicate a lack of hygiene of manipulators and surfaces because coliforms and the Salmonella sp. are found in the intestine of humans and warm-blooded animals, whereas Staphylococcus is naturally found in the human skin and mucosa, mainly in the mouth and nose.

Table 7. Microbiological analysis of the different zero-lactose ice cream bases.

\begin{tabular}{|c|c|c|c|c|c|}
\hline Treatment $^{\dagger}$ & $\begin{array}{c}\text { Coliforms at } \\
45^{\circ} \mathrm{C} \\
(\mathrm{CFU} / \mathrm{g})\end{array}$ & $\begin{array}{c}\text { Salmonella } \\
\text { sp. } \\
\text { in } 25 \mathrm{~g}\end{array}$ & $\begin{array}{l}\text { Coagulase } \\
\text {-positive } \\
\text { Staphylococci } \\
\text { (CFU/g) }\end{array}$ & $\begin{array}{c}\text { Psychotrophic } \\
\text { bacteria } \\
\text { (CFU/g) }\end{array}$ & $\begin{array}{c}\text { Mesophiles } \\
\text { Log } \\
\text { (UFC/g) }\end{array}$ \\
\hline $\mathbf{A}$ & $<10$ & Absence & $<100$ & $<10$ & $3.29 \pm 0.91 \mathrm{ab}$ \\
\hline B & $<10$ & Absence & $<100$ & $<10$ & $2.14 \pm 0.75 b$ \\
\hline $\mathrm{C}$ & $4.7 \times 10$ & Absence & $<100$ & $<10$ & $3.78 \pm 0.41 \mathrm{a}$ \\
\hline D & $<10$ & Absence & $<100$ & $<10$ & $3.38 \pm 0.47 \mathrm{ab}$ \\
\hline
\end{tabular}

${ }^{\dagger}$ A: mineral water base; B: rice extract base; C: zero-lactose milk base; D: mixed base.; CFU/g: colony forming units/gram. Source: Authors (2021).

Higher amount of coliforms, coagulase-positive Staphylococci, and Salmonella sp. in ice creams is associated with low levels of hygiene and sanitation during handling, raw material processing, and manufacturing, thus decreasing the shelf life of the product and increasing risks to consumers (Diogo et al., 2002; Benato \& Gallo, 2007; Queiroz et al., 2009).

During storage, psychotrophic aerobic heterotrophic bacteria were not detected (Table 8). Psychotrophic bacteria are found in the soil, vegetation, and water (Ribeiro et al., 2018; Santana et al., 2001) and grow between $0^{\circ}$ and $15^{\circ} \mathrm{C}$ (Franco, 2012). Their absence in the ice cream bases without lactose may indicate that the fruits, vegetables, and equipment used for production were effectively sanitized.

However, the growth of mesophilic bacteria was observed in the samples (Table 7). Their presence indicate processing and storage hygienic conditions as they develop at room temperature ranging between 20 and $37^{\circ} \mathrm{C}$ (Franco, 2012).

According to Table 8, treatment $\mathrm{C}$ had the highest amount of mesophylls (3.78 $\log \mathrm{CFU} / \mathrm{g}$ ) and shows no statistical difference with treatments D (3.38 log CFU/g) and A (3.29 log CFU/g), but has statistical difference with B (2.14 log CFU/g). 
Treatment D showed no statistical difference with treatments A and B. Finally, treatment A showed no statistical difference with B. No significant change in the mesophyll population was observed during storage $(p>0.05)$.

Thus, the amount of microbes found in our developed ice cream bases was within the limit of the International Commission on Microbiological Specifications for Foods (ICMSF, 1986), which determines that the population of this bacterium in food fit for human consumption should not exceed the $7.0 \log \mathrm{CFU} / \mathrm{g}$.

\subsection{Sensory analysis}

Our taste participants had higher percentage of women $(68 \%)$ than men (32\%). No participants declared themselves as other genders.

We found that $35 \%$ of the participants consumed ice cream weekly (Figure 1). The same percentage was found by Eiki et al. (2015). Maia et al. (2008) have analyzed the ice cream consumption habits and reported that $60 \%$ of their respondents consumed ice cream at least once a week. Thus, it is noted that ice cream consumption is constant. In addition, only $2 \%$ consumed ice cream daily, and $4 \%$ had never tasted ice cream.

Figure 1. Frequency of ice cream consumption by the tasters included in this study.

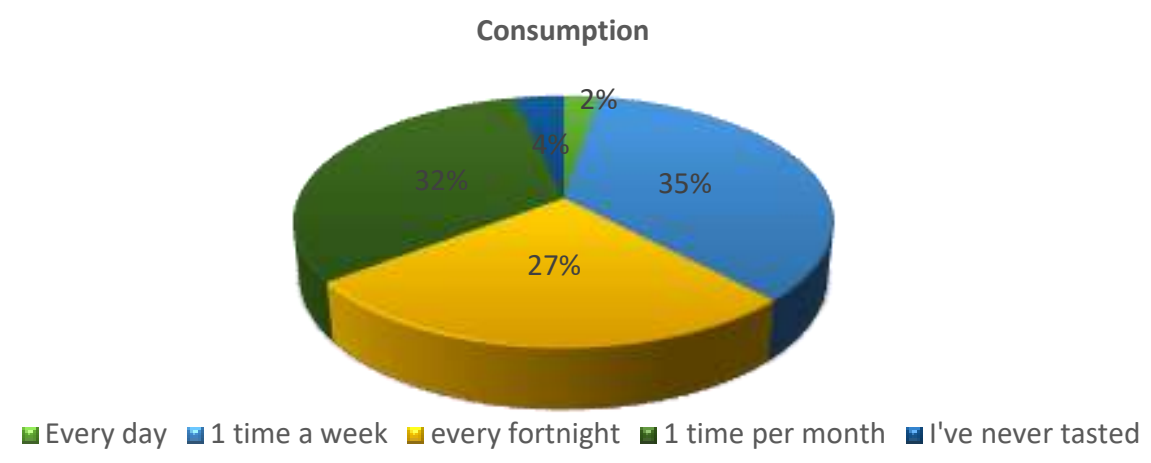

Source: Authors (2021).

Table 8 summarizes the consumer ratings of color, flavor, texture, and the general impression of the different ice cream bases at different storage period. 
Table 8. Consumer ratings obtained from the sensorial analysis of different artisan ice cream bases stored at 7 and 21 storage d.

\begin{tabular}{cccccc}
\hline $\begin{array}{c}\text { Storage Period } \\
\text { (days) }\end{array}$ & Characteristics & A & B & C & D \\
\hline $\mathbf{7}$ & Color & 3.7 & 4.3 & 6.6 & 5.6 \\
& Flavor & 4.4 & 4.0 & 6.7 & 5.1 \\
& Texture & 3.7 & 3.9 & 6.6 & 5.0 \\
& General & 3.4 & 3.8 & 6.5 & 5.3 \\
& impression & & & & \\
\hline \multirow{2}{*}{} & Color & 4.2 & 4.4 & 6.6 & 5.6 \\
& Flavor & 4.3 & 4.3 & 6.8 & 5.7 \\
& Texture & 4.0 & 4.4 & 6.5 & 4.9 \\
& General & 3.6 & 4.1 & 6.3 & 5.0 \\
& impression & & & & \\
\hline
\end{tabular}

Variables that do not have letters in the columns showed no statistically significant difference by the $t$-test at 5\% significance level. Source: Authors (2021).

There was no significant change $(p>0.05)$ in consumer acceptance of the different zero-lactose artisanal ice cream bases over time. Thus, principal component analysis (PCA) was performed to better visualize data clustering (Figure 2).

Figure 2. Principal component analysis (PCA) of the sensory analysis of lactose-free artisanal ice cream with different bases at 7 (A) and 21 (B) d of storage. A: mineral water base; B: rice extract base; C: zero lactose milk base; D: mixed base.
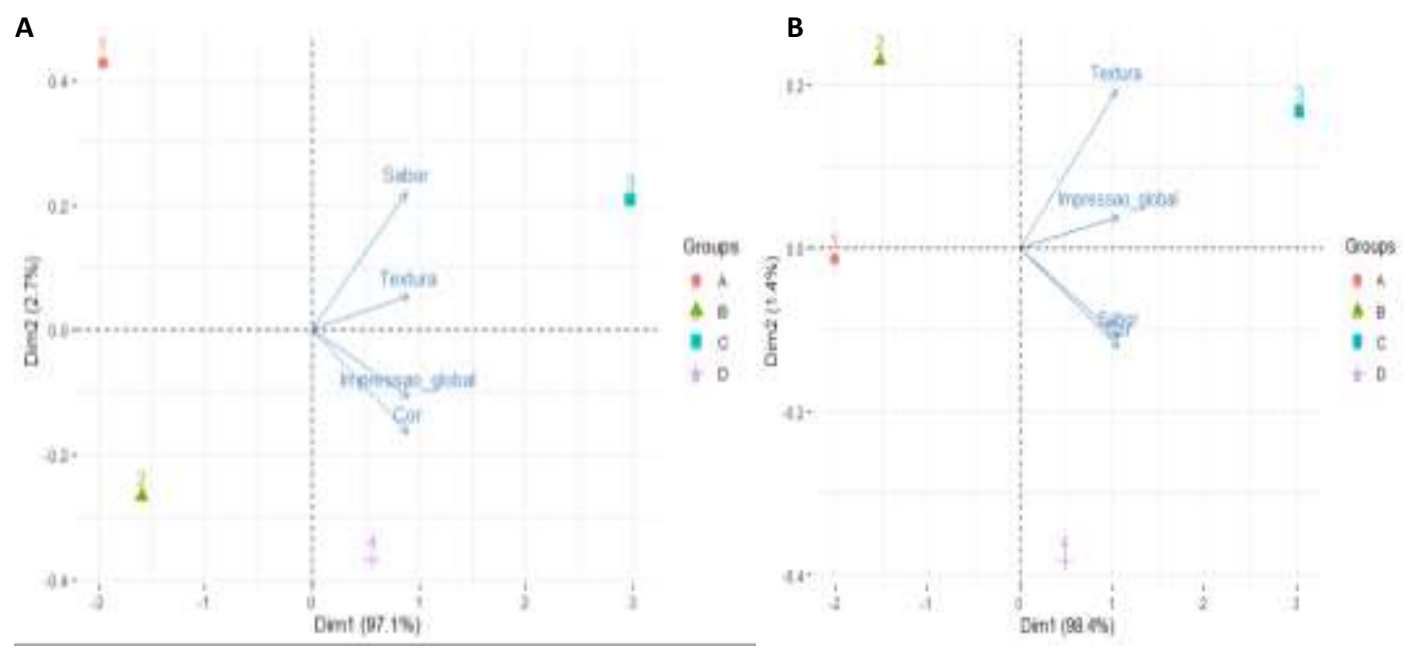

Source: Authors (2021).

Kale (Brassica oleracea L. acephala), yellow passion fruit (Passiflora edulis f. flavicarpa Deg.), Tahiti lime (Citrus latifolia - Tanaka), sucrose, and glucose were the key ingredients responsible for the organoleptic characteristics of the products and provide flavor and color to food. However, the different bases stored at different times showed no significant difference ( $p$ $<0.05$ ) in terms of color, flavor, texture and general impression (Figure 2A and 2B). 
After storage for $7 \mathrm{~d}$ (Figure 2A), PCA explained $97.1 \%$ in the first dimension and $2.7 \%$ in the second dimension. At 21 days (Figure 2B), PCA explained $98.4 \%$ in the first dimension and $1.4 \%$ in the second dimension. At both times, the autovectors indicate that treatment three had the greatest contribution to all characteristics among other treatments as it had the greatest distance from the origin in dimension 1 , thereby positively contributing to the result.

In dairy products, lipids provide flavor and increase its stability and body, whereas proteins stabilize and emulsify them, i.e., they link two heterogeneous phases and transform it into one homogeneous mass (Fellows, 2018). Milk, on the other hand, has a mild flavor, being slightly sweet, clean, and pleasant (Arcuri; Brito; Brito, 2008). This suggests that the flavor of all fruits and vegetables we used was enhanced in the base containing zero-lactose milk.

From Figure 3, the intention to purchase after 7 (Figure 3A) and 21 (Figure 3B) d of storage was unanimous for treatment C. The zero-lactose milk base, with more than $70 \%$. In the product acceptance test, sample C obtained the highest results, suggesting that its characteristics directly influenced the consumers' intent to purchase.

Figure 3. Purchase intention of the different zero-lactose ice cream bases at 7 (A) and 21(B) d of storage. 1: Would certainly buy; 2: Would probably buy; 3: Would maybe buy/not buy; 4: Would probably not buy; 5: Would certainly not buy. A: mineral water base; B: rice extract base; C: zero lactose milk base; D: mixed base.

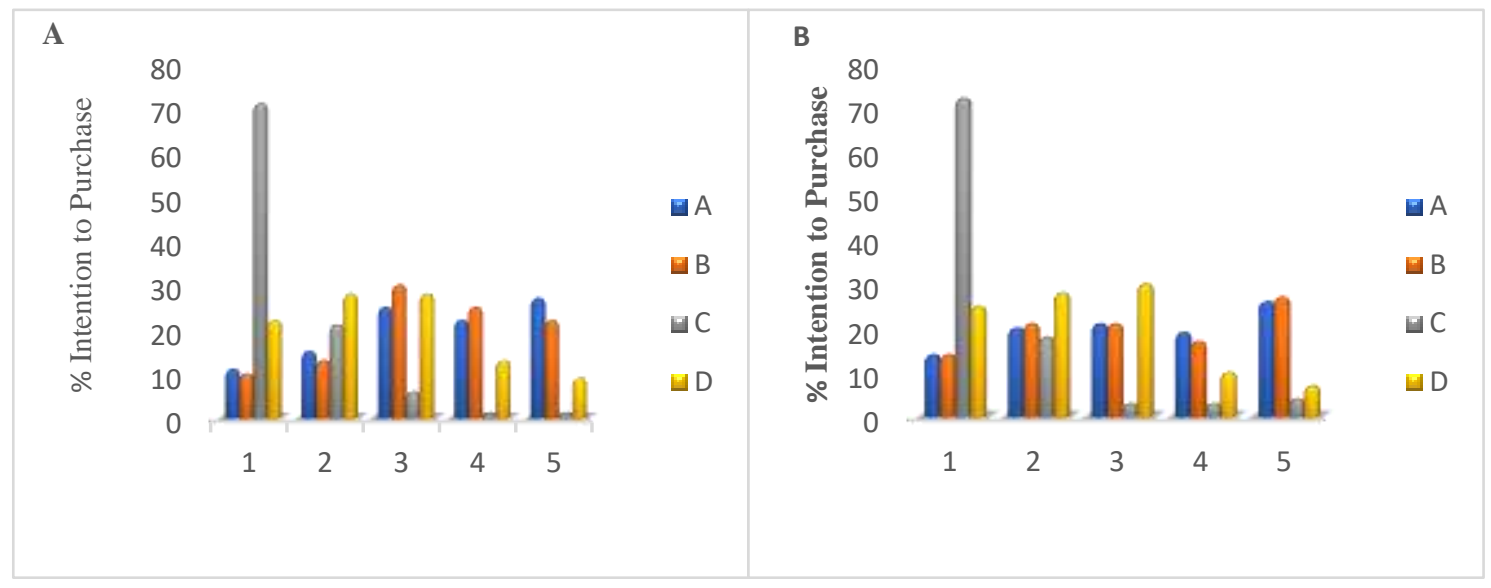

Source: Authors (2021).

\section{Conclusion}

Overall, our results showed that the four zero-lactose artisanal ice cream bases we have developed did not show significant difference in terms of color, flavor, texture, and general impression as rated by consumers. PCA, intention to purchase, and centesimal analysis showed that the zero-lactose milk base sample performed the best. However, all samples showed satisfactory physicochemical and microbiological characteristics and color properties and had shelf lives of 21 days.

Even though further studies are necessary for a careful cost-benefit to large scale production, our study provides a theoretical basis for the development of new flavors of artisan ice cream lactose-free to attend to the demand for vegans and lactose-intolerant individuals.

\section{References}

Association of Official Analytical Chemis. (2012) Official Methods SM Program Manual (19th ed). Arlington: AOAC International.

Adabo, G., Terão, D., Halfeld, B. de A.V., \& Nechet, K. de L. (2018). Atividade da enzima peroxidase em frutos de mamão (Carica papaya) submetidos a tratamentos físicos pós-colheita. Empresa Brasileira de Pesquisa Agropecuária-Embrapa: Meio Ambiente-Artigo, ${ }^{\circ} 12$. 
Abreu, A. (2012). A importância da inovação tecnológica na indústria de alimentos: um estudo de caso numa empresa de grande porte. XXXII Encontro Nacional de Engenharia de Produção Desenvolvimento Sustentável e Responsabilidade Social: As Contribuições da Engenharia de Produção, Bento Gonçalves, RS, Brasil.

Almeida, A. B. da S., Ferreira, M. A. C., Barbosa, T. A., Siqueira, A. P. S., \& Souza, E. R. B. de. (2016). Elaboração e avaliação sensorial de sorvete diet e sem lactose de mangaba endêmica do Cerrado. Journ Neotropical Agriculture, 3:38-41.

Aragão, D. de M., Araújo, Y. F. V., Carvalho, E. A. da S., Gusmão, R. P. de, \& Gusmão, T. A. S. (2018). Sorvetes sabor maracujá elaborados com biomassa da banana verde e sucralose. Rev. Verde Agroecologia Desenvolv. Sustent. Cien Saude Colet, 13:483-488.

Arcuri, E. F., Brito, J. R. F., \& Brito, M. A. V. P. (17 Sept 2019). Sabor e Aroma- Como Preservar, 2008. Retrieved from https://cienciadoleite.com.br/noticia/2821/sabor-e-aroma--como-preservar

Batista, R. A. B., Assunção, D. C. B., Penaforte, F. R de O., \& Japur, C. C. (2018). Lactose em alimentos industrializados: avaliação da disponibilidade da informação de quantidade. Cien. Saude Colet., 23:4119-4128.

Benato, R. T. R., \& Gallo, C. R. (2007). Comparação da eficiência dos caldos Escherichia coli e caldo verde brilhante lactose bile na enumeração de coliformes termotolerantes em leite e sorvete de massa. Rev Inst Adolfo Lutz (Impresso), 66:18-25.

Branco, M. de S. C., Dias, N. R., Fernandes, L. G. R., Berro, E. C., \& Simioni, P. U. (2017). Classificação da intolerância à lactose: uma visão geral sobre causas e tratamentos. Rev Ciênc Méd, 26:117-125.

Brasil. (2001). Resolução da Diretoria Colegiada $\mathrm{n}^{\mathbf{0}} 12$, de 02 de janeiro de 2001. Aprova o Regulamento Técnico sobre padrões microbiológicos para alimentos. Diário Oficial [da] República Federativa do Brasil, 139, 7-E, 2001.

Brasil. (2003). Ministério Da Saúde. Resolução da Diretoria Colegiada n ${ }^{\circ} 360$ de 23 de dezembro de 2003. Regulamento Técnico sobre Rotulagem Nutricional de Alimentos Embalados, tornando obrigatória a rotulagem nutricional. República Federativa do Brasil, Brasília, 26 de dezembro de 2003.

Brasil. (2005). Agência Nacional de Vigilância Sanitária. Resolução da Diretoria Colegiada no 266 , de 22 de setembro de 2005 Aprova o regulamento técnico para gelados comestíveis e preparados para gelados comestíveis, República Federativa do Brasil, Poder Executivo, Brasília, DF, 23 de set, 2005.

Brito, M. A., Brito, J. R., Arcuri, E., Lange, C., Silva, M., \& Souza, G. (2019). pH do Leite. Empresa Brasileira de Pesquisa Agropecuária- Embrapa.

Brito, K. D., Filho, J. I os S., Oliveira, H. B. L. de, Araújo, B. G. de, Neto, E. da P., \& Lima, F. C. dos S. (2017). Estudo experimental do limão Tahiti (Citrus latifólia Tanaka): composição físico-química e de minerais da polpa in natura e do resíduo albedo. Rev Principia Cien e Tecnológica do IFPB. João Pessoa, ${ }^{\circ}$ 37.

Botelho, S. de C. C., Hauth, M. R., Botelho, F. M., Roncatto, G., Wobeto, C., \& Oliveira, S. S. (2019). Qualidade pós-colheita de frutos de maracujazeiroamarelo colhidos em diferentes estádios de maturação. Rev Ciên Agrár, 62.

Cadena, R. S. (2008). Sorvete sabor creme tradicional e "light": perfil sensorial e instrumental. Universidade Estadual de Campinas, Faculdade de Engenharia de Alimentos, Campinas, SP. 108p. Dissertação (mestrado)

Calheiros, K. O., Brazaca, S. G. C., \& Souza, M. C. (2019). Avaliação da disponibilidade do ferro em dieta complementada com couve manteiga. Alimentos $e$ Nutrição Araraquara, 19:37-42.

Carlos, S. A. V., Amaral, L. A. do., Santos, M. M. R., Santee, C. M., Zampieri, D. F., Soares, W. R. G., Novello, D., \& Santos, E. F. dos. (2019). Elaboração de sorvete de cupuaçu utilizando fibra de casca de maracujá como substituto de gordura. Evidência-Ciência e Biotecnologia, 19:23-44.

Castro, T. M. N., Zamboni, P. V., Dovadoni, S., Neto, A. C., \& Rodrigues, L. J. (2015). Parâmetros de qualidade de polpas de frutas congeladas. Rev Inst Adolfo Lutz, São Paulo, 74:426-36.

Correia, R. T. P., Magalhães, M. M. A., Pedrini, M. R. da S., Cruz, V. F. da, \& Clementino, T. (2008). Sorvetes elaborados com leite caprino e bovino: Composição química e propriedades de derretimento. Rev. Ciênc. Agron., 39:251-256.

Coelho, B. E. S., Sousa, K. dos S. M. de, Silva, C. N. da, Santana, M. da S., Mudo, L. E. D., \& Alves, D. C. (2019). Desenvolvimento de sorvete a base de leite saborizado com polpa da romã 'wonderful'. Nucleus- Revista Cientifica da Fundação Educacional de Ituverava, 16:215-224.

Clarke, C. (2004). The Science of ice cream. Cambridge: Royal Society of Chemistry.

Diogo, G. T., Aguiar, G. M., Tolentino, M, C., Buffara, D., \& Pileggi, M. (2002). Avaliação microbiológica de sorvete comercializado na cidade de Ponta Grossa-PR e da água utilizada na limpeza das colheres utilizadas para servi-los. Publicatio UEPG-Ciências Biológicas e da Saúde, 8:23-32

Eiki, G., Hanai, L. N., Pires, L., Ekuni, M. M., \& Madrona, G. S. (2015). Aceitação sensorial de sorvete a base de vegetais. Geintec, 5:2569-2578.

Fellows, P. J. (2018). Tecnologia do Processamento de Alimentos-: Princípios e Prática. Artmed Editora.

Ferreira, E. B., Cavalcanti, P. P., \& Nogueira, D. A. (2018). ExpDes.pt: Pacote Experimental Designs (Portuguese). R package version 1.2.0. Retrieved from https://CRAN.R-project.org/package=ExpDes.pt. 14 nov. 2019.

Franco, R. M. (2012). Atlas de Microbiologia de Alimentos. Gráfica Editora Stamppa.

Goff, H. D., \& Hartel, R. W. (2004). Ice cream and frozen desserts. Handbook of frozen foods. Boca Raton: CRC Press.

Instituto Adolfo Lutz. (2008). Normas analíticas do Instituto Adolfo Lutz: métodos químicos e físicos para análise de alimentos (4th ed.).

Instituto Brasileiro de Geografia e Estatística. (2017). Produção agrícola municipal: culturas temporárias e permanentes. 43. 
International Commission on Microbiological Specifications for Foods (ICMSF). (1986). Microorganisms in Foods.2. Sampling for microbiological analysis: Principles and specifie applications (2nd ed.). Blackwell Scientific Publications.

Laurenti, C., \& Clemente, E. (2005). Avaliação da atividade da peroxidase em carambola (Oxalidacia averrhoa) em diferentes estádios de maturação. Acta Sci. Agron., 27:159-163.

Maia, M. C. A., Galvão, A. P. G. L. K., Modesta, R. C. D., \& Júnior, N. P. (2008). Avaliação do consumidor sobre sorvetes com xilitol. Ciênc. Tecnol. Aliment., 28:341-347.

Marciana, M. V., Marciano, M. V., Rauecker, U. N., \& Coelho, K. O. (2019). Consumo e acesso de produtos lácteos sem lactose. Rev Uningá, 56:58-65.

Marroquim, O. M. G., Borges, M. V. de V. F., Costa, J. G. da, Santos, A. F. dos, Panjwani, C. M. B. R. G., \& Vanderlei, A. D. (2019). Análise das propriedades físico-químicas das bebidas à base de fruta e seu potencial erosivo no esmalte dental. Diversitas, 4:580-599.

Mucke, L. R., Massarolo, L. P., \& Mucke, N. (2012). Estudo comparativo da qualidade de vegetais in natura e minimamente processados por meio da avaliação de parâmetros físico-químicos. Universidade Federal do Paraná. Medianeira-PR (Monografia).

Neves, M. V. M., \& das Lima, V. L. A. G. (2009). Efeito do congelamento sobre a estabilidade da polpa de acerola adicionada de extrato comercial de própolis. Alimentos e Nutrição Araraquara, 20:87-94.

Novo, M. do C. de SS., Prela. A. P., Trani, P. E., \& Blat, S. F. (2010). Desenvolvimento e produção de genótipos de couve manteiga. Hortic bras., $28: 3$.

Perfeito, D. G. A., Corrêa, I. M., \& Peixoto, N. (2017). Elaboração de bebida com extrato hidrossolúvel de soja saborizada com frutos do cerrado. Rev Agri Neo.l, Cassilândia-MS, 4:21-27.

Pereira, J. M. de A. T. K., Oliveira, K. A. M., Soares, N. F. F., Gonçalves, M. P. J. C., Pinto, C. L. O., \& Fontes, E. A. F. (2009). Avaliação da qualidade físicoquímica, microbiológica e microscópica de polpas de frutas congeladas comercializadas na cidade de Viçosa-MG Alimentos e Nutrição Araraquara, 17:437442.

Pereira, A. S.; Shitsuka, D. M.; Parreira, F. J.; \& Shitsuka, Ricardo. (2018). Metodologia da Pesquisa Científica1 ed. - Santa Maria, RS: UFSM, NTE, 1 e-book. Pinhão, R. (2012). A química do sorvete. Ensino de química. Universidade Federal Fluminense.

Queiroz, H. G. da S., Neta, N. do A. S., Pinto, R. S., Rodrigues, M. do C. P., \& Costa, J. M. C. da. (2009). Avaliação da qualidade físico-química e microbiológica de sorvetes do tipo tapioca. Rev. Ciênc. Agron. 40:60-65.

Ramos, E. M., \& Gomide, L. A. de M. (2007). Avaliação da qualidade de carnes: fundamento e metodologias. Ed, UFV.

Ribeiro, B. D. N., Pereira, R. P. do, Signori, K., \& Coelho, M. A. Z. (2018). Microbiologia industrial: Alimentos. Elsevier Brasil.

Santana, E. D., Beloti, V., Barros, M. D. A. F., Moraes, L. B., Gusmão, V. V., \& Pereira, M. S. (2001). Contaminação do leite em diferentes pontos do processo de produção: I. Microrganismos aeróbios mesófilos e psicrotróficos. Semina: Ciências Agrárias, 22: 145-154.

Santos, C. A. do A., Coelho, A. F. S., \& Carreiro, S. C. (2008). Avaliação microbiológica de polpas de frutas congeladas, Ciênc. Tecnol. Aliment, $28: 913-915$.

Silva, N. D., Junqueira, V. C. A., Silveira, N. F. de A., Taniwaki, M. H., Gomes, R. A. R., \& Okazaki, M. M. (2017). Manual de métodos de análise microbiológica de alimentos e água. (5th ed.). Blucher.

Silva, E. P., Becker, F. S., Silva, F. A. da, Júnior, M. S. S., \& Caliari, M., Damiani, C. (2015). Bebidas mistas de extratos de arroz com maracujá e mamão. Rev Inst Adolfo Lutz., 74:49-56.

Silva, S. R. da, \& Mercadante, A. Z. (2002). Composição de carotenoides de maracujá-amarelo. Ciênc. Tecnol. Aliment., 22:254-258.

Stone, H., Sidel, J., Oliver, S., \& Woolsey, A, Singleton, R. C. (1974). Sensory evaluation by quantitative descriptive analysis. Food Technol., 28:24-34.

Suri, S., Kumar, V., Prasad, R., Tanwar, B., Goyal, A., Kaur, S., Gat, Y., Kumar, A., Kaur, J., \& Singh, D. (2018). Considerations for development of lactosefree food. J. Nutr. Metab., 15:27-34.

Tabela brasileira de composição de alimentos/Nepa - Unicamp. (2011). Nepa - Núcleo de Estudos e pesquisas em Alimentação. (4th ed.). NEPA- UNICAMP.

Team, R. C. (14 Nov. 2019) R: A language and environment for statistical computing. https://www.R-project.org/

Valderrama, P., Fabiane, M., \& Clemente, E. (2001). Efeito do tratamento térmico sobre a atividade de peroxidase (POD) e polifenoloxidase (PPO) em maçã (Mallus comunis). Sociedade Brasileira de Ciência e Tecnologia de Alimentos.

Viana, D. S. Limão (Citrus latifolia, Tanaka), cv. tahiti, de cultivos convencional e orgânico biodinâmico: avaliação da capacidade antioxidante dos sucos in natura e clarificados por membranas de microfiltração- Universidade Federal do Rio de Janeiro, Faculdade de Farmácia, Rio de Janeiro, (2010). 100 f. Dissertação (Mestrado em Ciências Farmacêuticas).

Voet, D. (2008). Fundamentos de bioquímica: A vida em nível molecular. (2nd ed.). Artmed.

Wooten, W. J. (2010). Lactose Intolerance and Ethnic Prevalence, National Institutes of Health. Lactose Intolerance and Health. (p. 49-52). Kensington: National Institutes of Health.

Zeraik, M. L., Pereira, C. A. M., Zuin, V. G., \& Yariwake, J. H. (2010). Maracujá: um alimento funcional. Rev. Bras. Farm., 20:459-471. 